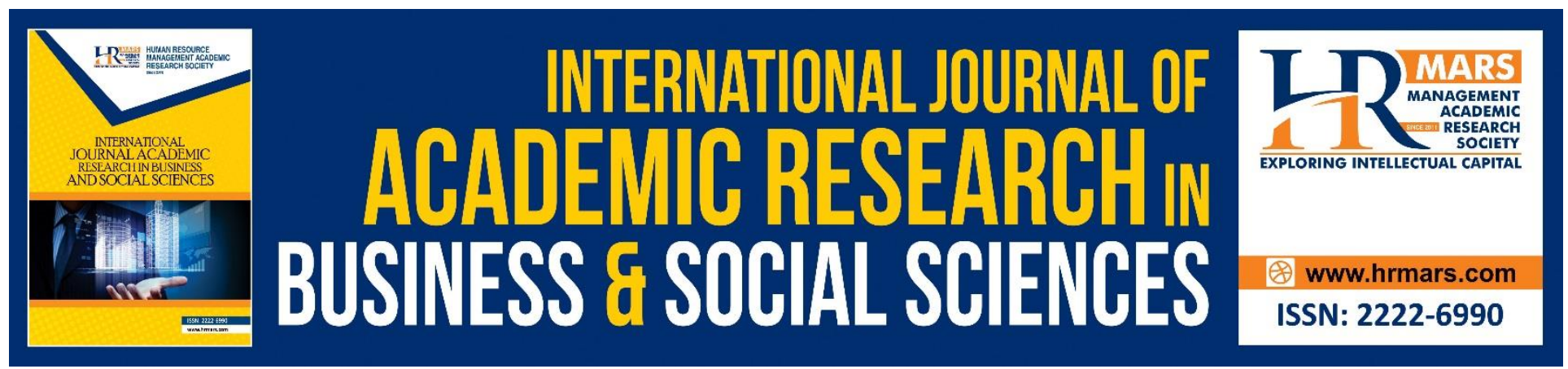

\title{
The Concept of Boycott: A General Introduction
}

\section{Anas Mohd Yunus, Wan Mohd Yusof Wan Chik, Najihah Abd Wahid, Khiral Anuar Daud, Mohammad Normaaruf Abd Hamid}

To Link this Article: http://dx.doi.org/10.6007/IJARBSS/v10-i9/7889

DOI:10.6007/IJARBSS/v10-i9/7889

Received: 07 July 2020, Revised: 30 July 2020, Accepted: 18 August 2020

Published Online: 21 September 2020

In-Text Citation: (Yunus, et. al, 2020)

To Cite this Article: Yunus, A. M., Chik, W. M. Y. W., Abd Wahid, N., Daud, K. A., Abd Hamid, M. N. (2020). The Concept of Boycott: A General Introduction. International Journal of Academic Research in Business and Social Sciences. 10(9), 962-971.

Copyright: (C) 2020 The Author(s)

Published by Human Resource Management Academic Research Society (www.hrmars.com)

This article is published under the Creative Commons Attribution (CC BY 4.0) license. Anyone may reproduce, distribute, translate and create derivative works of this article (for both commercial and non-commercial purposes), subject to full attribution to the original publication and authors. The full terms of this license may be seen

at: http://creativecommons.org/licences/by/4.0/legalcode

Vol. 10, No. 9, 2020, Pg. 962 - 971

http://hrmars.com/index.php/pages/detail/IJARBSS

JOURNAL HOMEPAGE

Full Terms \& Conditions of access and use can be found at http://hrmars.com/index.php/pages/detail/publication-ethics 


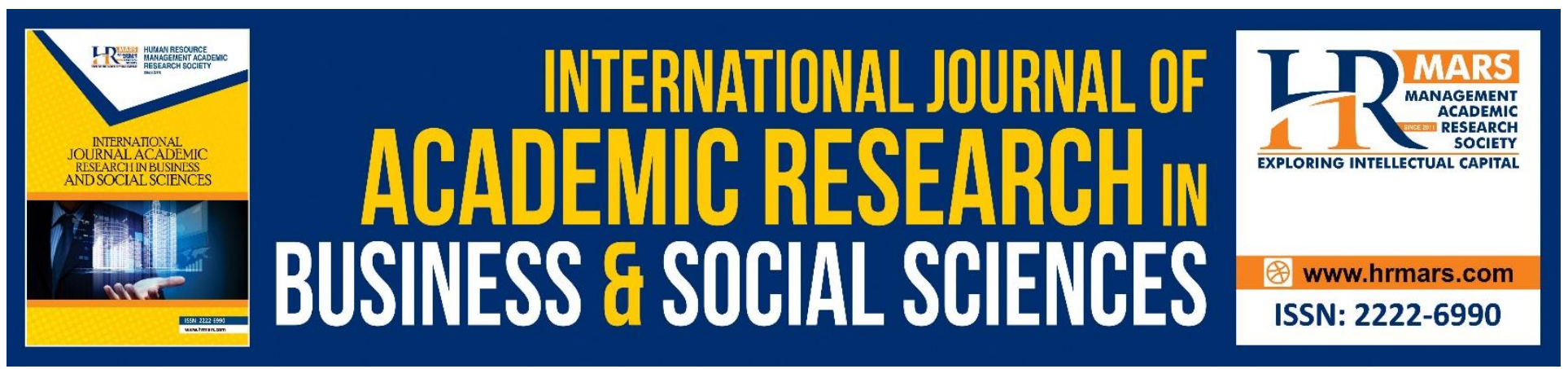

\title{
The Concept of Boycott: A General Introduction
}

\author{
Anas Mohd Yunus, Wan Mohd Yusof Wan Chik, Najihah Abd Wahid, \\ Khiral Anuar Daud, Mohammad Normaaruf Abd Hamid \\ Universiti Sultan Zainal Abidin \\ Email: anas@unisza.edu.my
}

\begin{abstract}
The term boycott is a common term among the community when used by certain parties to provide awareness at keeping alert on current issues. Boycott is one of the campaigns that is continuousy getting attention which often signals interest among communities worldwide. Scientific research on the general explanation of boycott remains at inadequate. Thus, this paper aimed to provide a general explanation in relation to boycott including its background, categories and goals. A qualitative method was used in this paper including the use of library research. Using a content analysis approach on the library materials, this paper analyzed the concept of boycott including its background and categories (aspects, approaches, actions taken, types of boycotted products and realistic boycott launch goals depending on the campain organizers). The findings of this paper found that the term boycott was taken from the name of a British Irish farm agent. Besides that, picketing, listing of 'injustices' or 'do not buy', strikes, refusal to interfere with other employers 'pickets and blacklists are actions that employ boycott. This paper serves as a suitable reference and guide for certain individuals or authorities because it explains the concept of boycott in general covering its background, categories and goals of a boycott launch.
\end{abstract}

Keywords: Boycott, Background, Categories, Goals.

\section{Introduction}

A boycott is a form of campaign that provides awareness to the general public regarding issues and rights fought by certain parties. It is part of jihad fi sabilillah through the context of property medium. This is because the obligation to conduct a boycott is based on the law of jihad, resulting a new form of jihad (Yunus et. al., 2014).

However, spatial and situational factors influence the implementation of the boycott. When the implementation of the boycott is seen in events that took place over the deaths of many Muslims in Palestine due to the atrocities commited by the Israeli, it is obligatory to implement such boycott and to ensure it is expanded. Thus, the law of boycott based on the protection of the lives of Muslims and the defense of Palestinian land and Jerusalem is fardu ain (Mohd Yunus et al., 2014). This is because Muslims are responsible for maintaining and preserving the sanctity of Islam (Mohammad et al., 
INTERNATIONAL JOURNAL OF ACADEMIC RESEARCH IN BUSINESS AND SOCIAL SCIENCES Vol. 10, No. 9, 2020, E-ISSN: 2222-6990 @ 2020 HRMARS

2020). Boycott is an action that is joined by one or more parties for a specific purpose by urging them not to buy certain goods or not to use certain services (Forno, 2013).

Thus, scholarly debate on basic and clear introduction of boycott remains at a low level. Therefore, this paper discussed in relation to the concept of boycott, including its terminological history and background. The following gist covered the categories of boycott including its aspects, approaches, action aspects and the types of boycotted products, as well as the launch goals of boycott campaigns.

\section{The Concept of Boycott}

The term originates from an English word 'boycott', used by an English farm agent in Ireland is Captain Charles Boycott who used a high rate rental collection method in 1880 . This method has caused outrage and dissatisfaction among the Irish community. As a result, they took steps against reaping fruits of their labor (McNamara, 2019). Boycott is an action to ensure the company is responsible for its employees, consumers, communities, minorities, animals or the environment (Murtagh \& Lukehart, d.a.)

Meanwhile, the term boycott in Malay language is a form or act of alienating, even refusing to hold any communication with others (Kamus Pelajar, 2015). It is also defined as an act performed by a group of people or traders to force or place pressure in order to stop financial or social affairs between individuals, companies or countries (Harver World Encyclopedia, 1978). The term boycott in Arabic used is al-Muqāța ah al-iqtişādiyyah which derives from the root word qāța a which indicates the prohibition of any economic or social relationship in accordance with the written social system (Anis et al., 2004). Dobscha (1998) argued that a boycott is related to the notion that consumers have the power or right to choose or not to choose over a product for unexpected reasons (Dekhil, Jridi \& Farhat, 2015).

Actions of boycott can lead to bots such as strikes, listing in the list of 'injustice' or 'do not buy', pickets, refusal to interfere with other employers 'pickets and the refusal of employers or employees to work for a particular product. A boycott campaign is launched to persuade consumers not to buy products from any non-union employer or those who are subjected to boycott (The Encyclopedia Americana, 1993). It is undeniable that a country will prosper rapidly due to its many entrepreneurs because they are the driving force of a country's economic development (Usop et al., 2018). However, boycotts can affect entrepreneurs.

Another action related to boycott is one that occurs which is then followed by blacklisting a person or company in order to be discriminated against. However, there is confusion between the use of the word boycott and embargo which means a ban on exporting goods to a foreign country (Grolier Academic Encyclopedia, 1985). The embargo strategy is commonly used in international relations. Embargo is an act in the form of banning (either in partial or complete prohibition) of merchant ships to enter and exit the port of a country with the intention of boycotting it. It is an act of economic restriction, which is considered as a legitimate trade ban. An act of embargo is different from a blockade committed during wars (The Encyclopedia Americana, 1993). Blockade or restriction is an action to restrict the entry of food supplies, weapons or communication into an area by force (either in partial or in full). An example of an embargo is seen during the war in the Gaza Strip where Israel blocked any form of aid to be channeled into the area (The World Book Encyclopedia, 1992). However, acts of blockade and embargo are different since the former is a form of violent action that does not go through a legal process, while the latter is an act of legal restriction through legal means (Yunus, 2012). 
INTERNATIONAL JOURNAL OF ACADEMIC RESEARCH IN BUSINESS AND SOCIAL SCIENCES Vol. 10, No. 9, 2020, E-ISSN: 2222-6990 @ 2020 HRMARS

\section{Categories of Boycott}

Based on the aforementioned descriptions, boycotts can be classified according to several criteria. Among them are its aspect, its approach, its action aspect and the type of boycotted products.

\section{i. Aspects of Boycott}

Some types of boycotts can be categorized based on the aspect of boycott. It is also related to the purpose for which the boycott was implemented. Among the categories of boycott that can be seen from the aspect of boycotts are:

\section{a) Boycott of Society}

This launch is an act of collective boycott (a group of people, organizations or citizens of a country) to not to conduct import transactions from the boycotted country or to stop production on their own initiative without involving the authorities or the government. In this case, the power of the community is determinant in order to see its effective results of boycott. The strength of the pressure onto the boycotted party increases as communal participation in this boycott increases (The Encyclopedia Americana, 1993; Yunus, 2012).

\section{b) Boycott from the Authorities}

This boycott is launched by the authorities of a place, such as the government of a country or a combination of several governments or resolutions that prevent transactions with the boycotted party. The government or authority of a place issues a resolution or decree of boycott officially whether in a state of peace or war as in the case of the boycott of the Arab state against Israel. Members of the Arab League agreed to support the Palestinians' struggle to defend their country's sovereignty from the Israeli occupation. The boycott began in $1922-26$ years before the formation of what became known as the State of Israel. The Arab Executive Committee of the Syrian-Palestinian Congress began calling for a boycott of business activities with Jews in 1933 (Sela, 2002).

The boycott and pickets were organized by the Arab Trade Organization against Jewish traders in 1934. The Arab Executive Committee declared the boycott of Israel a patriotic responsibility circa 1937. On 2 December 1945, the Consul of the Arab League issued an official declaration of boycott stating that Jewish products are not welcomed in the Arab world. Arab institutions, traders, organizations, commission agents and individuals are advised not to conduct any business including distributing or using any Zionist products (Feiler, 1998). This boycott is driven by the bodies that are authoritative towards their citizens.

\section{c) Boycott of International Bodies}

This boycott is an international boycott acted by a coalition of countries around the world. It is decided through a joint resolution, such as seen in the case in the United Nations (UN). A more accurate term used in this case of boycott is embargo or economic restriction. This is what happened to Pyongyang and Iraq, as examples.

Iraq was subjected to financial and trade sanctions by the United Nations Security Council on 6 August 1990 - 4 days after Iraq invaded Kuwait which continued until 22 May 2003 after the fall of Iraqi leader Saddam Hussein. Resolution 661 was used at its early stage of economic restriction. However, after the Gulf War in 1991, Resolution 687 was enacted which included the disposal of Weapons of Mass Destruction. The restrictions covered everything except food and medicine. Thus, in a boycott 
INTERNATIONAL JOURNAL OF ACADEMIC RESEARCH IN BUSINESS AND SOCIAL SCIENCES Vol. 10, No. 9, 2020, E-ISSN: 2222-6990 @ 2020 HRMARS

like this, only one body has the legal authority to issue an embargo ruling, namely the United Nations (UN) (CNN, 2020).

Boycotting against the results of community action is easier and commonly to be practiced, especially by Muslims. On the other hand, boycotts authorized by authorities and international bodies require more effort and actions because it is more complex and involves many stakeholders with power.

\section{ii. Boycott Approach}

There are two approaches in boycott: the first is the direct approach between the boycott and the boycotted party. Meanwhile, the second approach is an indirect approach where the boycott influences others to jointly perform similar actions against the boycotted party. This can be detected when the boycott is divided into two: namely primary and secondary boycott. Primary boycotts put direct pressure onto the employers who disagree with the union. The usual action taken in the case of a primary boycott is organizing strikes. Secondary boycotts include an invitation for others to boycott as well. However, there is also a tertiary approach that is to boycott any party that is indirectly related to the boycotted party (Tate \& Lake, 2011).

These three approaches of boycott are applicable and do not rest as academic theories based on historical experiences of boycott implemented by the Central Boycott Office (CBO) (Weiss, 2017). However, the act of boycotting in the current context requires a great deal of effort and detailed research, in addition to assessing the constraints and obstacles that exist as well as realizing the potential and capabilities that exist on the part of Muslims.

\section{iii. Boycott Action}

Actions that seem to suggest boycott are three, namely strike, picket and boycott. Although these actions are different in terms of approach, such actions are to place pressure onto a party to meet the demands of the party that organizes it. Most actions are based on cases involving employees and employers. However, such actions are also often found in cases involving general issues. Accordingly, Katuuk (1996) meticulously described all these actions, which was alse stated by Yunus (2012) as follows:

\section{Strike}

Strikes are among enterprise actions committed by employees to claim their rights in the workplace (Ahmad, 2018). Such acts serve various purposes. Among them, Economic Strike aims to force a wage or salary increase where its launch and involvement are among the workers. Secondly, strikes protesting the oppression of workers (or known as Unfair Labor Practice-Strike) in which workers or workers' associations stop working as a protest against employers' simple actions. Sympathetic Strike is another type of strike in which a member of a trade union or labor stop working not as a show of dissatisfaction with the working conditions, but as a way to support members of another trade union or labor who are on strike elsewhere. Meanwhile, General Strike is a larger strike action that covers all or most members of the workers or workers' union in a particular group or region (Katuuk, 1996; Yunus, 2012).

An Outlaw Strike is carried out without instructions or authority from the leadership of the workers/ labor association. Flash Strike of Quickie is a strike launched by certain members of a work association or workers done by stopping work without notice. Flash strikes belong to the category of outlaw strikes. Next, a Sit Down Strike where the strikers stop working, but do not leave the workplace, thus 
INTERNATIONAL JOURNAL OF ACADEMIC RESEARCH IN BUSINESS AND SOCIAL SCIENCES Vol. 10, No. 9, 2020, E-ISSN: 2222-6990 @ 2020 HRMARS

still taking control of the workplace facilities. Slow Strike is an action of an employee done by slowing down his work speed, but his work is not abandoned (Katuuk, 1996; Yunus, 2012).

Work strikes are actions taken by employees who put pressure on the employer to meet all the desired demands (Widiastiani, 2017). In addition, delaying work and refusing to work overtime is an action that belongs to committing a strike (Department of Industrial Relations Malaysia, 2013). However, strikes are not suitable to be applied because it is contrary to the principles of Pancasila Industrial Relations (Rumimpunu, 2014)

\section{Picketing}

To picket is to walk back and forth, acted by representatives of trade unions or workers, in front of the workplace entrance by carrying various posters to inform the public that there is a dispute between workers and employers. Participants involved expect the general public to support the workers or labor association. In addition to serve as a means to inform the public, picketing can also be used to obstruct workplace operations, and thus force employers to comply with the requirements of labor or labor associations. The effectiveness of picketing is strengthened when it receives an unwritten agreement between the workers' or labor associations to respect while not violating the picket rules of the workers' or workers' disputes. Thus, the existence of such agreement will cause transportation from or to the company to be halted, resulting the company to stop its operations. The effect of this action is that other officers working in the company are forced to quit their jobs (Katuuk, 1996; Yunus, 2012).

\section{Boycott Action}

Boycott other than boycott of products as already explained can also be classified into investment withdrawal and restrictions or divestment and sanction. Divestment is a term that is the opposite of investment that is releasing the holding of assets in a company in order to reduce the financial burden or as a political action to an entity so that the entity changes its attitude. It was once imposed on Sudan (Ding, et al., 2018). Sanction is a form of punishment taken by one or more countries to prevent or punish a country that commits an act of violence. Usually it is implemented comprehensively involving diplomatic, economic and military aspects (New Standard Encyclopedia, d.a.). It includes embargoes as imposed on Iran by the United States in 1987 for allegedly sponsoring international terrorism as well as aggressive action against neutral state-owned ships. In the crisis between Israel and Palestine, the BDS (Boycott, Divestment, Sanction) approach has been mobilized to put pressure on Israel in its policy on Palestine (Barghouti, 2011). In the issue of the Israeli-Palestinian crisis, alFaruqi has challenged the Zionist position in the Middle East and condemned the terrorist policies and criticized the atrocities committed against the people of Palestine (Abdul Rahman, et al., 2015). Accordingly, the more appropriate action taken by the Palestinian people working with Israel or the employees of any institution involved in the deal with Israel is to strike and picket. Boycott is more common and can be done by the international community, especially Muslims. While Divestment action, although not widespread and only involves those who are active in the business industry, it can still be done by these groups. As for sanctions, it is more complicated because it involves more than one powerful entity but in theory, it still has room for Muslims to do through the Organization of the Islamic Conference (OIC) (Yunus, 2012). Boycott is a very important action and it will have a big impact on the boycotted party if the involvement in the boycott action is large (GMO Inside, 2014). 
INTERNATIONAL JOURNAL OF ACADEMIC RESEARCH IN BUSINESS AND SOCIAL SCIENCES Vol. 10, No. 9, 2020, E-ISSN: 2222-6990 @ 2020 HRMARS

\section{i. Types of product}

The types of products boycotted include goods and services. Among the categories that have been targeted by boycott are consumer goods, academics, sports and culture.

\section{a) Consumer goods}

Consumer goods are the most widely used product to be boycotted. These include agricultural products, food products, health products, mass media, entertainment and publishing, beauty products, clothing products, investment and tourism sectors. Such a boycott can be seen during the boycott of the apartheid regime in South Africa (Fieldhouse, 2005). It is also stated that more than 100 local authorities have banned everything from South Africa (Hanna, 2016).

\section{b) Academic}

Academic boycott is done by boycotting all academic affairs, cooperation and cultural collaboration and any form of project with academic institutions in the country concerned. This was once done by the Association of University Teachers in Britain. The boycott was mobilized on Haifa University and Bar-Ilan in Israel as the universities were involved in formulating policies (settlements) of the Israeli government in the West Bank and Gaza (Weiner, 2005; Mohd Yunus, 2012). However, the academic boycott of Israel was blocked by a leading university in Africa, the University of Cape Town (Chernik, 2019)

\section{c) Sports}

Sports are also the subject of boycott campaigns. The Olympics, for example, were boycotted by the United States and followed by several other countries, including Malaysia, by not sending its football team even though it was eligible when the Soviet Union hosted the Olympics in 1980. It was a protest against the Soviet's occupation in Afghanistan. In 1984, the Soviet Union and its allies boycotted the Olympics organized by the Americans (Carter, 2010). All boycotts in this field can be done by Muslims. However, consumer goods are the most common target of boycotts because their participation usually consists of individuals and it is easy to implement. Compared to sports, academics and the like, it requires mandates and authority from the relevant parties.

\section{Purpose of boycott}

The purpose of boycotting depends on the party organizing the boycott campaign. In general, the main goal of a boycott is for the boycotted party to submit to the demands that led to the boycott. Such campaigns usually involve financial, religious, political, social and other factors.

\section{Conclusion}

Boycotting is a form of alienation committed a person or a particular party onto something. Various forms of actions that show the application of boycott include blacklisting, committing embargo and blockade. Categories of boycott, on the other hand, include aspects of boycott, its approachs, action aspects and types of boycotted products. Aspects of boycott include those who launched the boycott whether it is a boycott by the community, authorities and international bodies. Meanwhile, there are two approaches to boycott, namely the direct approach between the boycott and the boycotted party. Boycott actions include strikes, picketing and boycotts. Next, types of product range from consumer goods, academic to sports. Accordingly, the goal of launching a boycott must be clear and 
INTERNATIONAL JOURNAL OF ACADEMIC RESEARCH IN BUSINESS AND SOCIAL SCIENCES Vol. 10, No. 9, 2020, E-ISSN: 2222-6990 @ 2020 HRMARS

it depends on the organizers of the boycott who are fighting for certain rights for their benefits and certain parties. This is a general and concise discussion related to the introduction of the boycott and all matters related to the boycott including the implementation of the boycott.

\section{Acknowledgment}

This paper is a part of research project of Fundamental Research Grant Scheme (FRGS) entitled The Formation Of A Harmonious Model Of Boycott Items Based On Maqasid Shariah (FRGS/1/2018/SS103/UNISZA/02/4) that is funded by Malaysian Ministry of Education and managed by Center for Research and Innovation Management (CRIM), Universiti Sultan Zainal Abidin in Terengganu, Malaysia.

\section{Corresponding Author}

Anas Mohd Yunus, Universiti Sultan Zainal Abidin, Gong Badak Campus, 21300 Kuala Terengganu,

Malaysia.

Email:anas@unisza.edu.my

\section{References}

Abd Hamid, M. N., \& Yunus, M. A. (2020). The Application of Hifz Al-Din concept in Syariah-compliant Business Management. (Aplikasi Konsep Hifz Al-Din Dalam Pengurusan Perniagaan Patuh Syariah). International Journal of Islamic Studies and Social Sciences, 2(1), pp. 109-133.

Abdul Rahman, T., Rashid, M. Z., Yusof, W. S., \& Amir, A.N. (2015), The Conflict between Islam and Israeli in Palestine: Issue and Resolution in the works of Al-Faruqi. (Konflik Islam Dan Israel Di Palestin: Tentangan, Isu Dan Penyelesiannya Dalam Karya Al-Faruqi). UMRAN International Journal of Islamic and Civilizational Studies, 2(2), pp. Xx-Xx.

Abdul Talib, A.N., Abdul Latif, S. A., \& Alias, N. (2012). The Willingness to Boycott Among Malaysian Muslims. Konferens Pemasaran Islam Global Kali ke-3, https://www.researchgate.net/publication/259297918_The_Willingness_to_Boycott_Amon g_Malaysian_Muslims

Ahmad, M. (2018). The Development and Roles of Boycott in Malaysia: An Onset Research. (Perkembangan Dan Peranan Mogo di Malaysia: Satu Kajian Awal). Jurnal Kajian Sejarah dan Pendidikan Sejarah, 6 (2), pp. Xx-XX.

Anis, I., Muntasir, A., Ahmad, M. K. (2004), al-Mu jam al-Wasīţ, Maktabah al-Shuruq al-Dauliyah. Barghouti, O. (2011). Boycott, Divestment, Sanction. Chicago: Haymarket Books.

Carter, J. (2010). When Sport Gets Political, ESPN Sport Media Ltd, http://en.espn.co.uk/espn/sport/story/11477.html

Chernik, I. (2019). University of Cape Town Blocks Academic Boycott of Israel, The Jerusalem Post. https://m.jpost.com/israel-news/university-of-cape-town-blocks-academic-boycott-ofisrael-585316

CNN Editorial Research. (2020). Iraq Weapons Inspections Fast Facts. https://www.cnn.com/2013/10/30/world/meast/iraq-weapons-inspections-fastfacts/index.html 
INTERNATIONAL JOURNAL OF ACADEMIC RESEARCH IN BUSINESS AND SOCIAL SCIENCES

Vol. 10, No. 9, 2020, E-ISSN: 2222-6990 @ 2020 HRMARS

Dekhil, F., Jridi, H., \& Farhat, H. (2017). Effect of Religiosity On the Decision to Participate in A Boycott (The Moderating Effect of Brand Loyalty - the case of Coca-Cola). Journal of Islamic Marketing, 8(2), pp. 309-328.

Ding, N., Parwada, J. T., Shen, J., \& Zhou, S. (2018). When Does a Stock Boycott Work? Evidence from A Clinical Study of the Sudan Divestment Campaign. Journal Business Ethics. vol. 163. pp : 507527

Feiler, G. (1998). From Boycott to Economic Corporation: The Political Economy of Arab. Oxon: Frank Cass Publishers.

Fieldhouse, R. (2005). Anti-apartheid: a history of the movement in Britain: A study in pressure group politics. London: Merlin.

Forno, F. (2013). Boycotts. In The Wiley-Blackwell Encyclopedia of Social and Political Movements. doi:10.1002/9780470674871.wbespm016

GMO Inside. (2014). MO Inside's Plan For Change: What the Starbucks?!, https://www.greenamerica.org/blog/gmo-insides-plan-change-what-starbucks.

Grolier Academic Encyclopedia. (1985), vol. 10. Grolier International.

Hanna, M. (2016). BDS Movement: Lessons from The South Africa Boycott. AL-Jazeera Report, www.aljazeera.com

Harver World Encyclopedia. (1978). Vol. 4. Lousiana: Elseview Publishing Project.

Kamus Pelajar. (2015). $2^{\text {nd }}$ Ed. Kuala Lumpur: Dewan Bahasa dan Pustaka.

Katuuk, N. F. (1996). Official Industrial Relations. (Hubungan Industrial Pancasila). Jakarta: Penerbit Gunadarma Soepomo, Imam.

McNamara, R. (2019). Boycott. ThoughtCo., https://www.thoughtco.com/definition-of-boycott1773364

Yunus, M. A. (2012). Boycott against American products in Malaysia from the aspect of regulation. (Pemboikotan Terhadap Barangan Keluaran Amerika Syarikat Di Malaysia Dari Perspektif Hukum). PhD Thesis. Kuala Lumpur: Universiti Malaya.

Yunus, M. A., Abd Wahid, N., \& Hassan, W. S. (2014). The Rule of Boycotting on Israeli product based on Fiqh Al-Jihad. (Hukum Boikot Barangan Israel Berdasarkan Kepada Fiqh Al-Jihad). Jurnal Pengurusan Dan Penyelidikan Fatwa, 4, pp. 135-160.

Murtagh, C., \& Lukehart, C. (d.a). Co-op America's Boycott Organizer's Guide, United States: Washingston.

New Standard Encyclopedia. (d.a.), 12 ${ }^{\text {th }}$ Ed. Vol.32, Chicago: Standard Education Corp.

Rumimpunu, F. (2014). Official Industrial Relation System in Industry on Workforce and Industry from the Legal Aspect. (Work Force Act No. 13 Year 2003). (Sistem Hubungan Industrial Pancasila Di Indonesia Dengan Tenaga Kerja, Perusahaan Dilihat Dari Aspek (Undang-undang Tenaga Kerja No. 13 Tahun 2003). Jurnal Hukum, 11(2). Pp. 117-126. Universitas Sam Ratulangi : Indonesia

Sela, A. (2002). The Continuum Political Encyclopedia of the Middle East. New York: Continuum.

Tate, J. M., \& Lake, R. B. (2011). Taking Sides: An Overview of the U.S. Legislative Response To The

Arab Boycott Of Israel. Journal of International Law And Policy, 6(2), pp.613-634.

The Encyclopedia Americana. (1918). Vol.4. New York: Chicago.

The World Book Encyclopedia. (1992). Vol.2. Chicago: World Book Inc.

Tindakan Perusahaan Piket, Mogok Dan Sekat Masuk, Bahagian Perancangan dan Penyelidikan Dasar. (2013). Jabatan Perhubungan Perusahaan Malaysia (JPPM): Putrajaya 
INTERNATIONAL JOURNAL OF ACADEMIC RESEARCH IN BUSINESS AND SOCIAL SCIENCES

Vol. 10, No. 9, 2020, E-ISSN: 2222-6990 @ 2020 HRMARS

Usop, R., Zainol, F.A., Nordin, N., Abdul Wahab, N., \& Hadi, H. N.M. (2018). Penentu pemacu daya saing usahawan bumiputera di negeri Terengganu: satu analisis, Asian People Journal (ASP), 1(2), pp.185-196.

Weiner, J. (2005). Israeli Boycott: A Mistake. The Nation Magazine. https://www.thenation.com/article/archive/israeli-boycott-mistake/

Weiss, M. A. (2017). Arab League Boycott of Israel. Congressional Research Service (CRS Report). https://fas.org/sgp/crs/mideast/RL33961.pdf

Widiastiani, N. S. (2017). The Realities of Boycott in Official Industrial Constilation Relations. (Keberadaan Mogok Kerja Dalam Konstelasi Hubungan Industrial Pancasila). Jurnal Hukum, 3(2), pp. 147-162. 